\title{
RESEARCHPAPER
}

\section{Effect of age and sex on litter moisture level in deep litter rearing of Vanaraja chickens}

\author{
KULDEEP KUMAR PANIGRAHY ${ }^{1}$, KUMARESH BEHERA ${ }^{2}$, SASMITA PANDA ${ }^{2}$ AND \\ SHAILESH KUMAR GUPTA ${ }^{1}$
}

${ }^{1}$ Division of Livestock Production and Management, National Dairy Research Institute, KARNAL (HARYANA) INDIA

${ }^{2}$ Department of Livestock Production and Management, College of Veterinary Science and Animal Husbandry, Orissa University of Agriculture and Technology, BHUBANESWAR (ODISHA) INDIA

Email : kul.pani42@gmail.com

Article Info : Received : 03.08.2016; Revised : 26.08.2016; Accepted : 13.09.2016

The objective of this study was to evaluate the effect of age and sex on moisture level of litter material in Vanaraja chicken for nine weeks. One hundred fifty Vanaraja chicks ( 75 male +75 female) were used for experiment. Litter moisture levels were measure at an interval of 3 weeks. Litter from male group had a significantly $(p<0.05)$ higher moisture per cent than that of other two groups. Similar trend was also observed at 42 days of age. Moisture level between all three groups varied significantly $(\mathrm{p}<0.05)$. But at 63 days of age continued trend changes and litter materials from female group had a significantly $(p<0.05)$ higher moisture per cent than that of other two groups. Litter moisture per cent is a good indicator of antibacterial property of litter materials so it should be monitored regularly and should be changed at a regular interval.

Key words : Litter, Moisture, Age, Sex, Coccidia, Vanaraja

How to cite this paper : Panigrahy, Kuldeep Kumar, Behera, Kumaresh, Panda, Sasmita and Gupta, Shailesh Kumar(2016). Effect of age and sex on litter moisture level in deep litter rearing of Vanaraja chickens. Asian J. Bio. Sci., 11 (2) : 289-291.DOI : 10.15740/HAS/AJBS/11.2/289291. 